\title{
Polarization and Spectacle in the Spanish Political Talk Show 'La Sexta Noche' During the 2019 European Elections ${ }^{1}$
}

\author{
Àlvar Peris-Blanes \\ University of Valencia (Spain) \\ Javier Pérez-Sánchez \\ European University of Madrid (Spain)
}

This article analyses how in the main political talk show on television in Spain, La Sexta Noche, the main themes of the European agenda were silenced or conditioned by the themes of the national, regional and local agenda during the last European elections. The media debate was oriented towards an analysis of the results of national elections and the campaign for regional and local elections that allowed for a greater spectacle, thanks to the shock effect of such polarized ideologies and the trivialization of national politics. This research has studied all the shows of the programme broadcast as of the national elections on 28th April 2019 up until the European elections held on 26th May 2019, analysing the main topics covered and the kind and tone of discourses made. Due to the fact that controversial political issues are preferred to more relevant ones in order to generate a spectacle and bigger audiences, the results indicate that the political talk show analysed contributes to the trivialization of debates and the impoverishment of public space, aided by formal elements inherent in the infotainment genre.

Keywords: European elections, political talk show, La Sexta Noche, polarization, infotainment.

1 This work is part of the $\mathrm{R}+\mathrm{D}+\mathrm{i}$ Project "Estrategias, agendas y discursos en las cibercampañas electorales: medios de comunicación y ciudadanos" (reference CSO2016-77331-C2-1-R), granted by the Ministerio de Economía y Competitividad (Spanish Government) for the period 2017-2020 and developed by the Mediaflows research group (www.mediaflows.es). 
$\frac{72}{\frac{9}{g}}$ he European Election of 26 May 2019 was held in Spain at a time of great electoral activity, since on the same day there were the municipal and regional elections in many regions, and it took place almost a month after the April General Election. It was happened at a politically relevant time as regards issues for the future of the European Union and its citizens such as Brexit and immigration policy, amid rising xenophobic and Eurosceptic stances in many Member States. However, it had to compete for media and social attention with many other issues that had to do fundamentally with Spanish politics and the regional and local agendas. It must be taken into account that for most Spanish political parties that ran in this election, the result of the local and regional elections was interpreted as a kind of "second round" of the general election held a month before, due to their power to influence the policy for a pact and the formation of the Government. The Spanish political agenda was already rather disrupted by such emotionally intense and polarized issues as Catalan independence and the rise and consolidation of extreme right-wing parties. This latter issue was represented by the party Vox, which won 12 seats in the election to the Andalusian Parliament in December 2018, tipping the balance towards the formation of a Government led by the PP's candidate, Juan Manuel Moreno Bonilla. In addition, one month before the European election, it attained 24 seats in the General Election of 28 April, giving visibility for the only second time to this political option in the national Spanish Parliament since Franco's death (Blas Piñar, leader of the far-right party Fuerza Nueva, was elected an MP in the Spanish Parliament in 1979).

In order to discover if the European agenda has finally found a space in the Spanish media, and how it has done so, we wish to delve into the way the European Election was handled in one of the few television formats that address political matters at prime time in Spain. In particular, we have studied the case of the political talk show La Sexta Noche (La Sexta, 2013-present), which has become a benchmark of Spanish television since its premiere a few years ago, getting very good audience results every Saturday. This format, moreover, is an excellent reflection of the paths along which political communication runs in present times, which television entertainment has embraced with no qualms. It involves a relationship between entertainment and political discourse that has not been explored regularly before. On the other hand, for some time now it has been possible to observe how entertainment strategies have brazenly broken into the arena of information and politics, at least in Spain (Peris-Blanes and LópezRico, 2017), and at the same time how entertainment formats have incorporated politicians and their debates into their content. This scenario has led to a growing "spectacularization" of political discourse on television, to which a format such as La Sexta Noche contributes most especially.

\section{THE POLITICAL TALK SHOW ON SPANISH TELEVISION}

Politics and its expressions in the public space are undergoing a deep and wide transformation (López-García and Valera-Ordaz, 2017; Vaccari, 2013). The 
main characteristics of this period of transition in political communication, which appears to be hybrid and much more complex than the previous one (Chadwick, 2013), include the blurring of the lines separating the producers from information consumers or receivers; the comparison between facts and opinions; the confusion between public and private; and the disappearance of the distinction between information and entertainment (Delli-Caprini and Williams, 2011; Mazzoleni, 2010). The latter affects both the incorporation of entertainment rationale into political news - which generates a large dose of "spectacularization" in the informative discourse (Thussu, 2007) - and an increase in political content in entertainment programmes, in particular magazines and talk shows (Baum and Jamison, 2006). The phenomenon of fusion between information and entertainment known as infotainment (FerréPavia, 2013) has been variably dubbed in politics as "political infotainment" (Berrocal et al., 2014), "pop politics" (Mazzoleni and Sfardini, 2009) and more recently "politainment" (Berrocal-Gonzalo, 2017). We must pay attention to this circumstance bearing in mind that we are at a time when knowledge of public affairs and channels of collective participation are increasingly mediated (Esser and Strömback, 2014).

The political talk show is an unescapable part of this relationship between politics and entertainment television. It is a flexible hybrid genre blending information and opinion, and in which there is no need for a strict structure or elaborate argumentation (Montagut and Carrillo, 2017). For some time now, however, the presence of political talk shows on Spanish networks has experienced a notable increase to the point of establishing itself as the go-to format for creating opinion in the media (León-Gross and Gómez-Calderón, 2011). They are broadcast on practically all the networks, in almost all time slots (mornings, afternoons and evenings) and every day of the week, always following very similar guidelines. This is due to the homogenization of the Spanish television system, characteristic for a notable business concentration and an atavistic fear of innovation and risk (Francés and Peris, 2017; Bustamante, 2014).

We must associate this phenomenon with the process of re-politicization that Spanish society has undergone, or a good part of it, due to the economic crisis and the cases of corruption that have spilled over from the main political parties. This growing collective awareness took shape in 2011 with the " $15 \mathrm{M}$ " movement, when many citizens occupied the main cities' squares in a way analogous to similar experiences of citizens' emancipation occurring in other parts of the world such as the Arab Spring and Occupy Wall Street (Sánchez-Duarte, 2016). This willingness from citizens to actively participate in the public sphere would not have happened without the emergence of social media, especially Facebook and Twitter, as instruments of mass communication thanks to their horizontal nature and capacity for mobilization.

On the other hand, it should be borne in mind that the political talk show is a very cheap form of content that can give more than acceptable audience results, becoming a very profitable product for the networks and communication groups, which have needed to occupy more broadcasting time since the appearance of a wider range on offer thanks to Digital Terrestrial Television (DTT). Even so, it 
74 is true that over time these formats have ceased to be low cost, especially those that are broadcast at prime time and in the morning. Despite all of this, the political talk show continues to be considerably cheaper than fiction and large entertainment formats such as reality shows and talent shows (Oliva, 2013).

In recent times, several authors have tried to establish the characteristic elements of the genre (Montagut and Carrillo, 2017). One primary aspect is the "personalization" of political discourse (Bennet, 2012), which is perceived on three different levels. To begin with, there is the presenter category as the "master of ceremonies", who no longer acts only as a moderator of the debate, but actively participates in it, providing comments and making asides, often ironically, to lower the tension. This is an enunciative element that the political talk show has imported from classic talk shows. In their role as interviewers, they are often willing to let the candidate answer questions without interruption instead of constantly disputing the details, so that politicians are better able to control the final message they want to convey. Sometimes, the presenters even behave very familiarly and cordially with the politicians, even joking, in tune with the atmosphere sought in these programmes.

On a secondary level, there are the regular participants, who have become almost a new television star system. The profile of these collaborators is journalists currently specializing in politics, experts and former politicians, with the ability to carry on arguments with no apprehension, who are not intimidated by the "adversary" and who express themselves from a very discernible ideological standpoint. The figure of the usual collaborator is key to the success of these programmes. That is why a new species of "professional opinion-makers" has appeared, capable of speaking about any topic. It is common for each collaborator to participate in the talk show formats in the same communication group, though they are likely to be called upon in rival networks' programmes. It all comes down to a "market logic" (Landerer, 2013): the one who pays the most is the one who gets the most "combative" participants and the ones who manage to transmit their message more effectively, even if it is full of categorical judgments, aggressiveness or demagoguery, to which the audience adheres as part of the show.

And finally, there are the politicians themselves, whose role in these programmes is unquestionable when it comes to addressing current news. In the "mediatisation" inherent in these television formats (López-García, Gamir and Valera-Ordaz, 2018), the candidates have the opportunity to approach the viewer in a relaxed way in order to better explain their message. In return, the "determining factors of the environment" (Mazzoleni, 2010) force them to show a more personal side. It is about being empathetic with the audience, being perceived as just another person, familiar, with the same problems, desires and concerns as any citizen. It has also been verified that the fact of going on this type of television space gives politicians media attention, and above all much greater cost-effectiveness than that obtained through traditional rallies, and furthermore it is much cheaper. Taking these parameters into account, politicians, encouraged by their advisers, agree to participate in these infotainment programmes because 
they provide them with much more relaxed and less combative conversations than interviews with journalists carried out in strictly informative programmes.

Another of the fundamental characteristics in the genre is the "dramatization" of the discourse (Mazzoleni, 2010), which is achieved through the use of various strategies. To begin with, current affairs are constructed as a narrative, as a compendium of anecdotes and themes associated with "metapolitics", which overshadow proposals, policies and complex analyses of reality (Ortells-Badenes, 2012). The actors in the news in political talk shows, as Montagut and Carrillo (2017) argue, are described as "heroes and antiheroes" in speeches that resemble the methods of fiction while distancing themselves from journalistic formulas. Political and electoral polls contribute to this image created of politicians as "winners and losers", which appear very much in these programmes since they enable politics to be turned into a competition or a "horse race" (Maarek, 2009), especially during campaign and pre-electoral campaign periods.

This "dramatization" is also observed in forms and language, both in television production and in verbal and non-verbal communication, which seek to excite rather than describe in detail. For example, the arrangement of the set, with two sides of collaborators facing each other, not only physically but also ideologically, allows the discussion to be perfectly staged. The presenter stands in the middle, trying to put some order or shake up the set if necessary. Camera movements such as travelling shots are also used, mixed with close-ups that heighten the emotion and stand out, especially when the "split screen" is used. Deep chords suitable for creating tension sound continuously, which is not accidental. Neither is the insertion of montage effects, graphics in the form of headlines and a sensational phrase in the videos introducing the topics of the talk show. For its part, the collaborators' verbal communication is characteristic for its brevity, exaggeration, simplification and informal language, which is spiced up with a propagandistic, sweetened, warlike and emotional lexicon. This passionate package is complemented or mixed with a very affected, non-verbal language, full of fuss and exaggerated reactions.

Taking these characteristics into account, for years there has been an intense and contradictory debate by researchers, academics and experts about the value and effects of infotainment in general and of the political talk show in particular (León, 2010). We can all agree that political and plural debate in public space is an exercise in indisputable democratic maturity and a central element for the consolidation of full citizenship. In this sense, it seems appropriate to ask whether the political talk show, as it is conceived today, achieves this purpose and becomes an active agent in forming an informed citizenry. We cannot forget that the political talk show -while we still cannot be sure of its decisive contribution to agenda-building (McCombs, 2006) — is a genre that contributes enormously to setting what the current issues are (León-Gross and Gómez-Calderón, 2011) and what the opinions on these issues are within a "mediatisation" process whose negotiation involves the media, politicians and social agents (Hepp, Hjarvard, and Lundby, 2015).

For some authors, therefore, infotainment —and by extension the political talk show, too- implies a degradation and trivialization of information and a 
strategy for citizens' passivity and resignation (Langer, 2000). An increasingly impoverished public agenda engaged in anecdotes and superficiality (Blumler, 1999; April 1997), a lower bar for journalistic principles and a loss of prestige for current affairs programmes may be some of its consequences (Redondo and Campos, 2015). For others, introducing political content into entertainment can be "empowering" (Hartley, 2000; Brants, 1998), because it makes it easier for many people not initially interested in these issues to become more informed, share arguments and opinions, and become aware of what is happening. From these points of view, the political talk show could have a democratizing function and a liberating, inclusive potential (Harrington, 2008), since it opens up public debate to new stakeholders and issues, mitigating the intense disaffection detected towards politics in some sectors, especially among the youngest and least educated.

\section{RESEARCH METHODOLOGY: THE CASE OF 'LA SEXTA NOCHE'}

One of the programmes best suited to the purpose of this research is, as we have mentioned, La Sexta Noche. The Atresmedia Group's format has established itself as the referential talk show within the Spanish media panorama. This programme was presented by Iñaki López and Andrea Ropero at the beginning, though the latter has been replaced by Verónica Sanz. It combines interviews with people from political, social and media spheres, with the debate about the news provided by collaborators who regularly or occasionally participate together with guest politicians from the main parties.

There are several reasons we have selected this programme as the main subject of this work. Firstly, there is the fact that this format has been one of the programmes with the biggest audience at prime time on Saturday. Since its premiere in the 2012-2013 season, the format has had a large average audience and for some seasons it has been one of the bastions of the network, obtaining results clearly above the average for La Sexta. For example, its best figures were obtained in the 2014-2015 season, when the programme had an average audience of 1,449,000 viewers, meaning an $11.9 \%$ share, while the average for La Sexta in 2015 was $7.4 \%$. In the last season for which there are records, 2019-2020, the results were closer between the programme and its network, with an $8.0 \%$ average for the programme and $7.3 \%$ for the network.

Secondly, La Sexta Noche, the only political talk show surviving on Spanish television at prime time, has served throughout these years as an indisputable platform for the transformation of recent Spanish politics. Indeed, it has been a television platform for emerging political forces such as Podemos and Ciudadanos, who have been able to defend their arguments and articulate an alternative stance as opposed to the traditional parties in Spain, PSOE and PP. The leaders of these newer formations, Pablo Iglesias and Albert Rivera, as well as other members of their parties, have appeared on their sets on many occasions. The possibility of giving a voice to these political options at prime time has made it possible for citizens to gain a better idea of their postures and thoughts, and for 
that same reason they are able to become legitimate options when deciding to vote. In this sense, perhaps without intending to, the programme has been able to play a decisive role in defining the political playing field for Spanish politics today, though it is difficult to specify the extent of its influence. In any case, it has made it possible for the main political parties to have visibility at prime time within a general network and consequently to provide a platform for a plurality of voices and ideas during its broadcasting time.

The sample is made up of the four shows of La Sexta Noche that were broadcast during May 2019. This period goes from the General Election held on 28 April until the day of the European, regional and local elections on 26 May. The period includes the programmes dedicated to the assessment and handling of the results of the General Election, as well as the programmes broadcast during the campaign for the European, regional and local elections. If we take into account that each of the programmes lasts approximately four hours, we have more than 990 minutes (practically one thousand minutes) of television. In those days in May, La Sexta Noche obtained results in line with the season (4 May, 8.9\% share; 11 May, 7.2\%; 18 May, 4.8\%; and 25 May (the day of reflection), 7.7\%). The audience obtained on 18 May stands out negatively, very far from the usual results, but it is understandable if we notice that the night was dominated by TVE's La 1 with the Eurovision Song Contest, one of the television events of the year, which obtained 5,449,000 viewers and a screen share of $36.7 \%$.

Based on this material, we intend to address the following research hypotheses:

- H1: Despite the undoubted interest in the issues on the European agenda that were discussed in these elections, the conditions of Spain's internal politics have silenced or greatly conditioned any attempt to insert them into the media debate.

- $\quad$ H2: The programme prioritizes domestic politics because doing so fosters the dialectical and ideological conflict, argumentative simplicity and the trivialization of debates that the programme requires, with the consequent impoverishment of the public space.

To respond to these hypotheses, we carried out a quantitative content analysis combined with a qualitative one. In the first place, a content breakdown was used to determine the contextualization and thematic agenda of the programmes in the sample, indicating the content and the topics discussed, as well as their relationship with the European election. We intended to learn in detail whether European issues that concern us as European citizens were discussed on the programmes, and the responses from the Spanish political parties to the challenges that were put into play in those elections. The data has been obtained via manual coding using the software SSPS in which the two authors have participated, achieving a reliability of $82 \%$.

To know the main themes of the campaign for the European Election of May 2019, we visited the websites of the main parties (PSOE, PP, Unidas Podemos, Ciudadanos, VOX and Esquerra Republicana de Catalunya) and we crossreferenced the programme's data to observe the matching issues were treated from 
78 different points of view. The topics are as follows: immigration policy; Catalonia and the Euro-order; employment and social policy; trade and the economy; Eurozone and Brexit; foreign policy, defence and security; climate change and the environment; Common Agricultural Policy; constitutional reforms; and Erasmus. The first five topics took up more time in debates, rallies and interviews, while the other five topics were less important in the media despite being in the parties' electoral manifestos and part of the European agenda.

To respond to the second hypothesis in this study, we carried out a qualitative analysis based on the previous breakdown of the topics covered in the programme. This has allowed us to interpret why some issues have been prioritized over others, and what has been the role of the European agenda. To do so, we looked at the programme's level of "personalization" and "dramatization", and therefore the intensity of the "spectacularization", following the characteristics of the genre (Montagut and Carrillo, 2017) explained above.

\section{RESULTS}

La Sexta Noche has focused mainly on evaluating the General Election held on 28 April and the issues related to the Regional and Municipal Elections, which were on the same day as the vote for the European Parliament.

Table 1. Breakdown of the main themes of 'La Sexta Noche' in May

\begin{tabular}{l|l|l} 
Topic & Total accumulated time in minutes & Programmes \\
\hline $\begin{array}{l}\text { Results of elections to the Spanish Parliament on } \\
28 \text { April and formation of Spanish Government, } \\
\text { also includes: } \\
\text { Interview with Borja Semper (PP) }\end{array}$ & $414^{\prime}$ (50' Semper) & $\begin{array}{l}\text { 04-05-2019 } \\
11-05-2019 \\
18-05-2019 \\
25-05-2019\end{array}$ \\
\hline Death of Rubalcaba & & $11-05-2019$ \\
\hline $\begin{array}{l}\text { Municipal and regional elections include: } \\
\text { Interview I. Errejón and M. Carmena (Más }\end{array}$ & $15^{\prime}$ & $11-05-2019$ \\
Madrid), Gabilondo (PSOE) and Ayuso (PP) & Gabilondo and Ayuso). & $18-05-2019$ \\
\hline European elections & & $25-05-2019$ \\
\hline $\begin{array}{l}\text { SuperSunday Programming Interview Antonio G. } \\
\text { Ferreras and Ana Pastor }\end{array}$ & $52^{\prime}$ & $25-05-2019$ \\
\hline $\begin{array}{l}\text { Interview Juanra Bonet } \\
\text { VOX }\end{array}$ & $70^{\prime}$ & $25-05-2019$ \\
\hline $\begin{array}{l}\text { Interview Jordi Évole } \\
\text { Other topics (interviews Cristina Almeida, Julia }\end{array}$ & $81^{\prime}$ & $25-05-2019$ \\
\hline
\end{tabular}


Illustration 1. Graph of the percentage of time dedicated to each topic

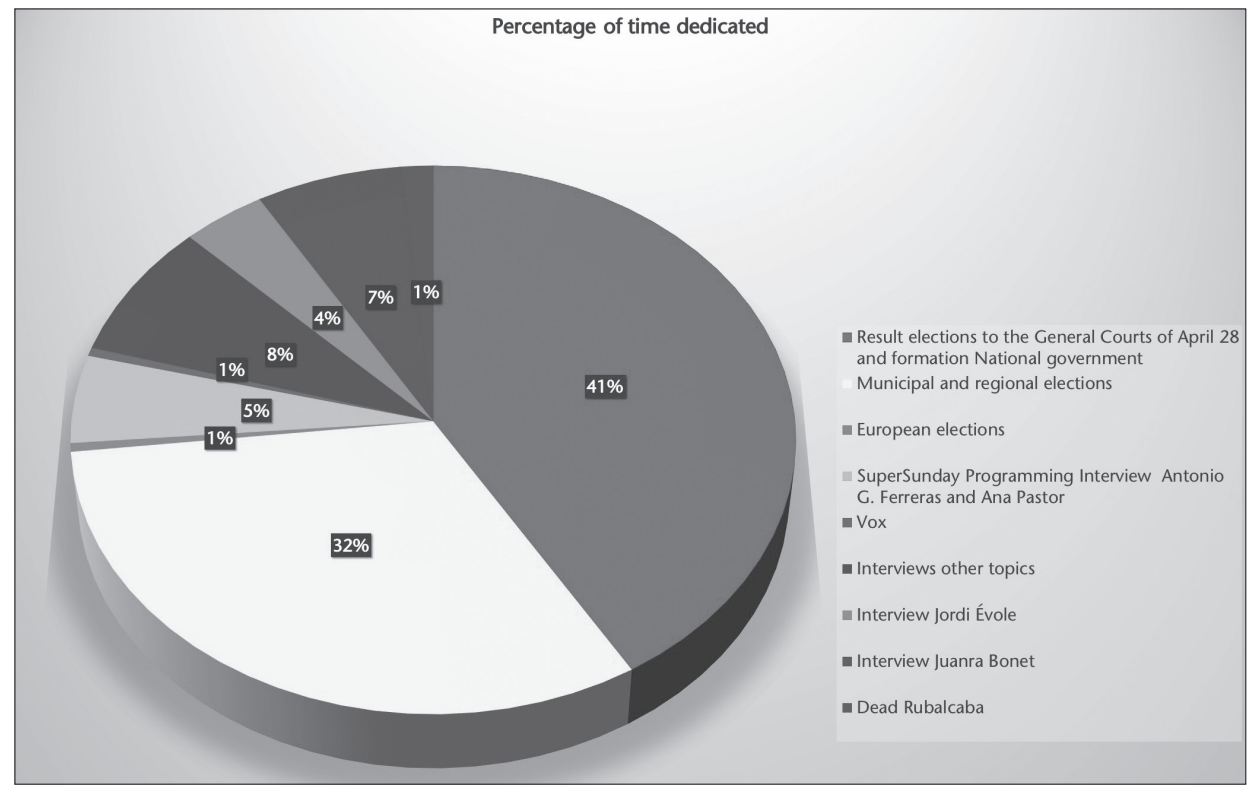

As can be seen in Table 1 and Illustration 1, out of a total of almost 1,000 minutes of television broadcast, the European Election was only specifically discussed for two short minutes, which represented $0.22 \%$ of the total. This is a surprisingly low figure if we take into account that it is a programme dedicated to analysing political and social news, and which emphasizes the different elections. At the other end of the scale, if we add up the time of the four programmes that make up the sample, almost half (41\%) were devoted to analysing the results of the General Election. The outcome was favourable for the progressive parties (PSOE and Podemos) but the resulting total of MPs was not sufficient to form an absolute majority for a Government, which forced them to seek other support in minority Catalan and Basque nationalist forces. The topics in these debates, such as the appearance for only the second time in the modern Spanish Parliament of an extreme right party, Vox, which got 24 seats, took up a lot of media and social attention, as can be seen in the discussions and comments in La Sexta Noche.

Furthermore, 32\% of the broadcasting time was dedicated to comments among the regular participants and other guests about the municipal and regional elections with which the European Election shared the day. Especially relevant is the time the programme spent on the Madrid Community Region and City Council, with several interviews with the candidates of the different parties facing each other on that occasion. This fact should be taken into account because not even the same attention was devoted to other important municipalities in 
which there were elections to elect mayors, such as Barcelona, Valencia and Seville. Behind that, at a great distance, the time dedicated to interviews with two journalists from the Atresmedia Group (to which La Sexta Noche belongs) stands out, such as with Juanra Bonet, presenter of ¡Boom! (Antena 3), and Jordi Évole, presenter at that time of Salvados (La Sexta) and one of the network's most recognizable and respected faces who has recently embarked on new projects.

Despite the scant attention that La Sexta Noche gave to the European Election being held, these four programmes dealt with issues on the European agenda, though usually within debates that had to do with national and local policy issues. On the set of La Sexta Noche programmes analysed, as in Table 2 and in Illustration 2, there were 82 minutes on issues related to the European agenda, representing $8.23 \%$ of the total minutes computed. Most of that time, however, was devoted to an issue that has generated a lot of controversy in Spain, and above all within political and media circles, which was the possibility of the EU issuing a Euro-order at the request of the Spanish Government to enable the arrest of Catalan politicians who left in their day so as to not be imprisoned by the Spanish authorities for organising an illegal independence referendum, including the former President of the Catalan Government or Generalitat, Carles Puigdemont. We are talking about $72 \%$ of those 82 minutes, that is, $59^{\prime}$. In fact, in the programme, independence was linked to the rise of the extreme right in Spain, which puts it on a par with other European countries as in the cases of the Matteo Salvini's Lega Nord in Italy, Marine Le Pen's National Front in France and other examples in Hungary and Germany.

To a lesser extent, there was also talk of climate change and European environmental regulations (13\%), especially the demands that the EU will make in future to combat climate change which in many countries are not being met. This issue came up when the candidates for the presidency of the Regional Community of Madrid were interviewed (Ángel Gabilondo of the PSOE, Isabel Díaz-Ayuso of the PP and Íñigo Errejón of Más Madrid), and the candidate in the municipal election and incumbent mayor of Madrid, Manuela Carmena. She described the Madrid Central project launched by the City Council to restrict motor vehicle access in a large area in the centre of the Spanish capital. Out of all of them, only Errejón and Carmena placed the debate within European environmental policy. European migration policy, with $1 \%$ of the total, at a time when Vox was rising and entering the Spanish Parliament, was also analysed. There was also talk of the economy and the common market (6\%) in relation to what happens in other EU countries with cases similar to the donations of large fortunes, such as the one made by the owner of Inditex, Amancio Ortega, of 310 million euros to the Spanish public health system in the spring of 2019. There was very little mention of the Common Agricultural Policy (1\%) and some about Brexit and its consequences (3\%), which took up only a maximum of three minutes coinciding with the moments in which the European elections were commented. 
Table 2. Topics in relation to the European elections on 'La Sexta Noche' in May 2019

\begin{tabular}{|c|c|c|c|}
\hline Topic & Section of the program & $\begin{array}{l}\text { Airtime } \\
\text { On }\end{array}$ & Programmes \\
\hline Euro-order / Catalonia & $\begin{array}{l}\text { Debate (journalists) } \\
\text { Interview (Jordi Évole) } \\
\text { Debate (politicians) } \\
\text { Debate (politicians) } \\
\text { Debate (politicians) } \\
\text { Debate (journalists) }\end{array}$ & $\begin{array}{l}5^{\prime} \\
5^{\prime} \\
21^{\prime} \\
9^{\prime} \\
14^{\prime} \\
5^{\prime}\end{array}$ & $\begin{array}{l}04-05-2019 \\
04-05-2019 \\
04-05-2019 \\
11-05-2019 \\
18-05-2019 \\
25-05-2019\end{array}$ \\
\hline Brexit & Debate (journalists) & $2^{\prime}$ & $25-05-2019$ \\
\hline Immigration & Debate (journalists) & $1^{\prime}$ & 04-05-2019 \\
\hline $\begin{array}{l}\text { Employment and social } \\
\text { measures Europe }\end{array}$ & $\begin{array}{l}\text { Debate (politicians) } \\
\text { Debate (journalists) }\end{array}$ & $\begin{array}{l}1^{\prime} \\
2^{\prime}\end{array}$ & $\begin{array}{l}04-05-2019 \\
25-05-2019\end{array}$ \\
\hline $\begin{array}{l}\text { Economy and common } \\
\text { market }\end{array}$ & $\begin{array}{l}\text { Debate (politicians) } \\
\text { Debate (journalists) }\end{array}$ & $\begin{array}{l}2^{\prime} \\
3^{\prime}\end{array}$ & $\begin{array}{l}04-05-2019 \\
25-05-2019\end{array}$ \\
\hline Common Agricultural Policy & Debate (journalists) & $1^{\prime}$ & $25-05-2019$ \\
\hline Climate change & $\begin{array}{l}\text { Interview (Manuela Carmena and } \\
\text { Errejón) }\end{array}$ & $11^{\prime}$ & $11-05-2019$ \\
\hline
\end{tabular}

Source: The Autors.

If we only stick to the issues directly or indirectly related to the EU addressed by the political representatives invited onto the programme, we have to point out that the main issue was Catalan independence within Europe. In fact, out of the 47 minutes in which politicians talked about the European Elections, for 44 minutes (almost the entirety) they focused on talking about the Catalan sovereignty movement. Something similar happened with the debates or discussions among journalists, in which more than half of the time dedicated to mentioning Europe was also occupied by the matter of independence, for 10 minutes out of a total of 19. As we can see, this issue was central when addressing the European Election. 


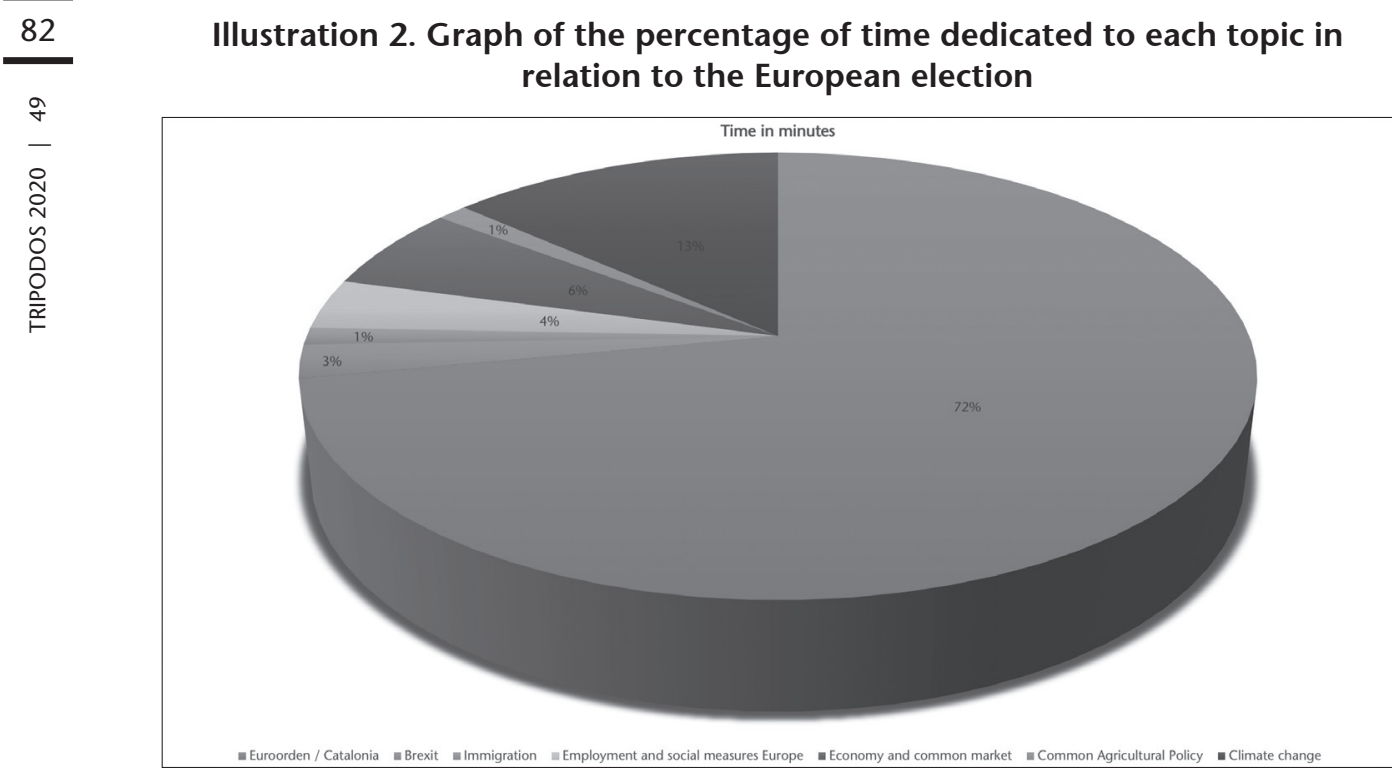

Source: The authors.

To end, it should be noted that there was no specific interview with any politician heading any of the parties' lists in the European Election. The politicians interviewed were candidates for municipal and regional elections. This undoubtedly shows the level of attention given to some elections compared to others; so much so that it was considered preferable to interview numerous journalists and people from the media world (the aforementioned Évole and Bonet, the journalist Julia Otero and the chef Alberto Chicote) rather than politicians who expressly talk about the importance of the European Election for Spanish citizens.

\section{DISCUSSION AND CONCLUSIONS}

The European Election on 26 May 2019 was of great importance for the Spanish population because of the significance of the issues at stake. In recent years, the EU and its institutions have been experiencing an unprecedented crisis of legitimacy and unpredictability. The main reason for this lies in the inability of its leaders to find satisfactory answers to the challenges they face daily. Immigration policy stands out above all issues, generating enormous tensions among the Member States. Similarly, the climate emergency caused by global warming, to which EU member countries contribute dramatically, was an issue on which all eyes were placed and urgently needed to be addressed by European institutions.

These are some of the issues concerning the EU that are especially relevant to the future of our societies. However, the main political talk show on Spanish television, La Sexta Noche, preferred to overlook and largely ignore them. 
According to the results presented, therefore, we can confirm the first of our initial hypotheses (H1), which is that the issues on the European agenda were diluted by internal code policy. It was deemed preferable to discuss the outcome of the General Election of 28 April or the municipal and regional elections rather than seriously consider the major challenges that Spain faces as a EU Member State. In some way, La Sexta Noche had the possibility of becoming an extraordinary vehicle to encourage real public debate, delve into the electoral manifestos of the different parties and, in general, to channel the different projects that the political parties had for Europe in future. Instead, it preferred to talk about politics in fundamentally self-referential terms and about "metapolitics", such as possible government pacts after the General Election, and electoral polls or slogans in the municipal and regional elections. But above all, there was much talk about the independence of Catalonia, an issue that has conditioned recent Spanish public opinion in many ways.

This may be due to the fact that La Sexta's news programmes' television attention is spread out and therefore there were other programmes concentrating more on Europe, but this absence in La Sexta Noche is still significant. Perhaps the network distributed its dedication to the European Election among the news spaces in its programming schedule. For example, La Sexta's other format of infotainment broadcast at prime time on Sunday, El Objetivo, presented by the journalist Ana Pastor, organized a debate with the candidates of the different parties to the European Parliament. In any case, that should not be an excuse for the belittling and disregard for the European agenda by La Sexta Noche during the period studied.

It is possible that the format's characteristics conditioned the inclusion of the European agenda. If we agree that La Sexta Noche seeks to compete for audience at prime time, the tendency will be to enhance the issues that are more polarized, generating more controversy and confrontation, in line with infotainment. All this is consistent with the characteristics of the genre we have described. The commitment to national politics instead of European politics, therefore, can be understood by this rationale of stirring up "passions" both on the set and among the studio audience, who are direct witnesses to heated arguments that avoid political complexity. To achieve this "spectacular" discursive construction of political content, La Sexta Noche stands out for using a whole series of formal elements and television production that allow a greater "personalization" of politics and "dramatization" of the content it seeks, which would confirm our second working hypothesis $(\mathrm{H} 2)$.

In the first place, "personalization" is confirmed in La Sexta Noche, both in relation to the leaders of the parties that appear (who are scrutinized even in their daily, intimate life) and the usual collaborators, who acquire great fame. In their comments, consensus is not sought in any form and there is not enough effort to recognize others' positions when disagreeing with them, or to see how positive their approach may be, even if they are wrong. On the contrary, confrontation and permanent argument are sought with the ideological polarization they create. These participants are vehement and insolent. They do not let the others finish their arguments, continually gesture in an affected way, speak with arrogance and 
their lexicon is in general quite limited and simple, full of appeals to "electoral battles" and "winners and losers". Obviously, there are more extreme cases than others, and there are a few who intervene forcefully but contribute to knowledge and enrich the debate. It seems fair to say that two of the usual collaborators of La Sexta Noche, the right-wing journalists Francisco Marhuenda and Eduardo Inda, have almost become television characters, a caricature of themselves. This issue shows the importance of emotions and feelings within the recent political discourse, far removed from ideas and proposals (Richards, 2010).

As for the "dramatization", La Sexta Noche has several sets distributed within a huge set, with a live audience and punctuated with spectacular lighting and camera movements, very similar to any other prime time entertainment programmes. Especially noteworthy in this task is the layout of the main set, with two opposing lines of 3 or 4 chairs where the guests and participants are located according to their ideological leanings and who are placed face to face to be able to ask questions directly, which clearly favours an argument and a contest. In this way, the participants are treated as if they were fiercely about to start a fight, always under the moderation of the presenter, who acts as a referee, the one who grants and removes the right to speak, and even places sanctions if the level of the attacks exceeds certain limits, which happens often. The role of the presenter is very active, since in addition to leading the discussion, he often thinks and participates in the debate. This organization of the main set is accompanied by numerous other sections, with an audience always ready to applaud or cheer on the interventions that for whatever reason have had more impact, either because of their argumentative forcefulness or because they have "knocked out" their rival. On the other hand, the use of serious, constant music, always in the background and rising in transitions, contributes to emotionally heighten the discussion, as is the case with the abundance of close or very closeup shots, which highlight the emotionality of the speaker. In addition, graphic elements are used profusely to deepen the dialectical confrontation between two participants, such as the split screen or the insertion of subtitles with their most forceful or controversial phrases. In short, it is a television production that is no different from the classic talk show and reality television formats (Imbert, 2008).

Based on this study, it follows that, despite the importance of the European Election for citizens, it was not a priority for the programme as long as there were aspects of national and local politics that enabled it to maintain the level of spectacle needed to achieve the desired audience results. In this sense, there is high "mediatisation" (Strömback, 2008), since it is the programme that chooses the topics to talk about, and which coincide with those that generate the most polarization, according to the classification proposed by Hallin and Mancini with respect to Spain (2004). Therefore, there are many doubts about the contribution of the political talk show to the creation of a truly European democratic public space.

In the end, formats like this demonstrate that the matter of politics is dealt with as a conflict but not as an area of rational debate. On the contrary, the information is banalized and what remains is noise. It may be true that through the political talk show there are people who know more about politics, but what 
kind of politics? Is the importance of the EU better known after watching the programme? What does each party propose for the future of Europe? Do we know? Certainly, not much. What is observed is that the political talk show, at least in the case of La Sexta Noche, is a pretext for profitable television time, where it sells more anger than real political debate. In some ways, these formats are economically profitable and that is why they are kept on television, though they contribute little to citizens being better informed. This permanent confrontation could even lead to cynicism and political disaffection among the public, instead of being stimulating.

\begin{abstract}
Àlvar Peris-Blanes (alvar.peris@uv.es). PhD in Media Studies from the University of Valencia, where he is an Assistant Professor in the Degree in Media Studies and in the Official Master's in Media Contents and Formats. He is Secretary of the Department of Theory of Languages and Communication Sciences. His main interests as a researcher are the analysis of media formats, the relationship between television entertainment and politics, and the media's construction of identities. He is the author
\end{abstract}

Javier Pérez-Sánchez (javier.perez@ universidadeuropea.es). Professor at the Faculty of Social Sciences and Communication at the European University, and codirector of the Shooting Minds Cinema Media Clinic. He has been Director of the Master of Motion Graphics Prisa TV (2012 to 2015) and he also managed the University Television Laboratory from 2013 to 2018. He has a PhD in Communication. His research career mainly focuses on the television field, having published articles in various indexed journals on television selfpromotions, analysis of television formats, of numerous scientific papers published in academic journals, monographs and collective books on communication, cultural studies and history. He has been a Visiting Professor at Duke University (USA) and at the University of Nottingham (United Kingdom). He participates in several research projects and is a member of the R\&D group Mediaflows (www.mediaflows. es). He has collaborated in the magazines Caràcters, Lletres Valencianes and Saó, and in several digital media.

television programming, hybridization of the Spanish audiovisual system and other studies. He has participated in more than a dozen international communication congresses. He has a monograph and several book chapters. In 2015 he obtained the Teaching Innovation Award from the European University. Since 2013 he has been a Member of the Academy of Sciences and Arts of Television for his career spanning more than a decade in television as a director and producer in national, international and regional networks. He is also a member of the R\&D Group Mediaflows (www.mediaflows.es). 


\section{References}

Abril, Gonzalo (1997). Teoría general de la información. Madrid: Cátedra.

Baum, Matthew A. and Jamison, Angela S. (2006). "The Oprah Effect: How Soft News Helps Inattentive Citizens to Vote Consistently". Journal of Politics, 68, pp. 946-959.

Bennet, W. Lance (2012). "The Personalization of Politics: Political Identity, Social Media, and Changing Patterns of Participation". The Annals of the American Academy of Political and Social Science, 644(1), pp. 20-39.

Berrocal-Gonzalo, Salomé (ed.) (2017). Politainment: La política como espectáculo en los medios de comunicación. Valencia: Tirant Humanidades.

Berrocal, Salomé; Redondo, Marta; Martín, Virginia, and Campos, Eva (2014). "La presencia del infoentretenimiento en los canales generalistas de la TDT". Revista Latina de Comunicación Social, 69, pp. 85-109.

Blumler, Jay (1999). "Political Communication Systems all Changes". European Journal of Communication, 14(2), pp. 241-249.

Brants, Kees (1998). "Who's Afraid of Infotainment?". European Journal of Communication, 13(3), pp. 315-336.

Bustamente, Enrique (2014). "El caso español: Mutación ideológica de modelos". In: Francés, Miquel; Gavaldà, Josep; Llorca, Germán, and Peris, Àlvar (coord.). La televisión de la crisis ante el abismo digital. Barcelona: Gedisa, pp. 15-28.

Chadwick, Andrew (2013). The Hybrid Media System. Politics and Power. Nueva York: Oxford University Press.

Delli-Caprini, Michael X. and Williams, Bruce A. (2011). After Broadcasting News. New York: Cambridge.

Esser, Frank and Strömback, Jesper (eds.) (2014). Mediatization of Politics. Understanding the Transformation of Western Democracies. New York: Palgrave McMillan.
Ferré-Pavia, Carme (ed.) (2013). Infoentretenimiento. El formato imparable de la era del espectáculo. Barcelona: UOC.

Francés, Miquel and Peris, Àlvar (2017). "Producción, oferta y consumo televisivo español en tiempos de crisis". In: Orozco-Gómez, Guillermo (coord.). Gestión y consumo de contenidos digitales. Nuevos modelos. México: Sahagón Repoll, pp. 83-129.

Hallin, Daniel and Mancini, Paolo (2004). Comparing Media Systems. Cambridge: Cambridge University Press.

Harrington, Stephen (2008). "Popular News in the 21st Century. Time for a New Critical Approach?". Journalism, 9(3), pp. 266-284.

Hartley, John (2000). Los usos de la televisión. Barcelona: Paidós.

Hepp, Andreas; Hjarvard, Stig, and Lundby, Knut (2015). "Mediatization: Theorizing the Interplay Between Media, Culture and Society". Media, Culture \& Society, 37(2), pp. 314-324.

Imbert, Gérard (2008). El transformismo televisivo. Postelevisión e imaginarios sociales. Madrid: Cátedra.

Landerer, Nick (2013). "Rethinking the Logics: A Conceptual Framework for the Mediatization of Politics". Communication Theory, 23, pp. 239-258.

Langer, John (2000). La televisión sensacionalista. El periodismo popular y las "otras noticias". Barcelona: Paidós.

León, Bienvenido (2010). "Introducción: información y espectáculo en un nuevo ecosistema informativo". In: León, Bienvenido (coord.). Informativos para la televisión del espectáculo. Sevilla; Zamora: Comunicación Social, pp. 17-29.

León-Gross, Teodoro and Gómez-Calderón, Bernardo J. (2011). "La tertulia en España: medios públicos, la última frontera de la pluralidad". Estudios sobre el mensaje periodístico, 17(1), pp. 67-80. 
López-García, Guillermo and Valera-Ordaz, Lidia (eds.) (2017). Pantallas electorales. El discurso de partidos, medios y ciudadanos en la campaña de 2015. Barcelona: UOC.

López-García, Guillermo; Gamir-Ríos, José, and Valera-Ordaz, Lidia (2018). Сотиnicación política: Teoría y enfoques. Madrid: Síntesis.

Maarek, Phillippe J. (2009). Marketing político y comunicación. Claves para una buena información política. Barcelona: Paidós.

Mazzoleni, Gianpietro (2010). La comunicación política. Madrid: Alianza.

Mazzoleni, Gianpietro and Sfardini, Anna (2009). Politica Pop. De 'Porta a Porta' a 'L'isola dei famosi'. Bologna: Il Mulino.

McCombs, Maxwell (2006). Estableciendo la agenda. El impacto de los medios en la opinión pública y en el conocimiento. Barcelona: Paidós.

Montagut, Marta and Carrillo, Nereida (2017). “Estrategias de espectacularización en las tertulias políticas televisives. Caso de la cobertura de las Elecciones municipales de Barcelona de 2015". El Profesional de la Información, 26(4), pp. 621-629.

Oliva, Mercè (2013). Telerrealidad, disciplina e identidad. Los makeover shows en España. Barcelona: UOC.

Ortells-Badenes, S. (2012). "Infoentretenimiento y periodismo político en televisión". In: Casero-Ripollés, A. (ed.). Periodismo político en España: Concepciones, tensiones y elecciones.
Tenerife: Cuadernos Artesanos Latina, pp. 99118.

Peris-Blanes, Àlvar and López-Rico, Carmen M. (2017). "Los programas de entretenimiento: Espectáculo y emoción en la comunicación política española". In: López-García, Guillermo and Valera-Ordaz, Lidia (eds.). Pantallas electorales. El discurso de partidos, medios y ciudadanos en la campaña de 2015. Barcelona: UOC, pp. 129-151.

Redondo-García, Marta and Campos-Domínguez, Eva (2015) "Implicaciones éticas del infoentretenimiento televisivo". Comunicació. Revista de Recerca i d'Anàlisi, 32(1), pp. 73-89.

Richards, Barry (2010). "News and the Emotional Public Sphere". In: Allan, Stuart (ed.). The Routledge Companion to News and Journalism. New York: Routledge, pp. 301-311.

Sánchez-Duarte, José Manuel (2016). "La red como espacio para la militancia política: tecnología y participación en campaña electoral". Communication \& Society, 29(3), pp. 33-47.

Strömback, Jesper (2008). "Four Phases of Mediatization: An Analysis of Mediatization of Politics". The International Journal of Press/ Politics, 13(3), pp. 228-246.

Thussu, Dayan K. (2007). News as Entertainment. London: Sage.

Vaccari, Cristian (2013). Digital Politics in Western Democracies. A Comparative Study. Baltimore: John Hopkins University Press. 